\title{
The National Politician Language Style: Fadli Zon
}

\author{
Andre Febra Rilma ${ }^{1}$, Ermanto ${ }^{2}$, Novia Juita ${ }^{3}$ \\ \{andrefebra62@student.unp.ac.id ${ }^{1}$,ermanto@fbs.unp.ac.id ${ }^{2}$, noviajuita@fbs.unp.ac.id ${ }^{3}$ \} \\ ${ }^{1,2,3}$ Universitas Negeri Padang, Jl. Prof. Dr. Hamka Air Tawar Padang Sumatera Barat 25131, \\ Indonesia
}

\begin{abstract}
This study examines the style of language used by national politicians Fadli Zon. This research is qualitative research with descriptive method. This research gives a systematic, factual and accurate description (description) of the facts, nature, and relationship between the phenomenon under investigation. The descriptive method in this research is used to obtain accurate data description to simplify the process of analysis. The technique of collecting data in this research using also using technique refer and note. In this study found there are seven styles of the language used by Fadli Zon that is alusio, repetition, hyperbole, simile, irony, metaphor and oxymoron. The most widely used language styles are repetition and hyperbole.
\end{abstract}

Keywords: Cohesion, language style, politics, fadli zon.

\section{Introduction}

Language and politics are two inseparable things. Language is used for political purposes. Politics basically exists in everyday life. Politics is a matter of power, namely the power to make decisions, control resources, control the behavior of others and often control the values of others. Even ordinary decisions made every day can be viewed from a political standpoint [1].

Politics can include many types of activities, starting from; (a) national policy-making process (government politics), (b) gender equality (sexual politics); (c) competition in groups that are closely interwoven, such as competition between office partners in positions which are usually done by leaking or keeping secrets (office politics ), (d) the way people negotiate the roles they must carry out in their personal lives; (e) history of the political system, (f) activities related to transportation, settlement, and consumption that can affect the environment (environmental politics). Therefore, we actually cannot escape from political problems[1].

The use of the language style is not only found in written texts but also in oral works, such as education. Didek itself is one of the art forms of speech that is owned by the people of Selayar Islands, South Sulawesi. The use of the style of language is indirectly examined, making it difficult to fulfill the function of a poetic language. The style found in the chorus includes diction and figures of speech. Dictations include the selection of denotative, connotative, and suggestive meanings. The style of language used in the study consists of litotes, personification, redundancy, hyperbole, repetition, paradox, and metaphor. [2].

Language has tremendous strength in achieving political goals. The linguistic strategies used in political discourse are implicature, euphemism, lexicalization, grammatical structures, metaphor, and hyperbolism. With this linguistic strategy, one of the goals to be achieved by 
politicians is to persuade listeners or citizens to believe in the validity of the claims of a politician [3].

Another research findings that language is not merely a communication tool or a code or value system that arbitrarily designates a monolithic reality. The language of the prospective governor of South Sulawesi in accordance with the maxim of language politeness tends to follow the maximal award means reducing criticism to others and adding praise to others[4].

Language and linguistic practices are no longer understood in the context of a conventional perspective, namely as a tool and a neutral medium used to explain sociopolitical realities. However, it is increasingly realized that the language in itself appears as a representation of and space for the deployment of various kinds of power. For example, in the 2009 election, the political language used tended to be persuasive and hyperbole, which was exaggerating from the actual reality [5]. Not limited to Linguistic research only. Research on language style is also done in the research of a literary work. Another research found that the style of language in the novel Pesantren Impian by Asma Nadia was dominated by the use of metaphorical language styles and paradoxical language styles[6]. So the style of language is not only used with spoken language as in the research conducted by Yusri , Budianto , and Dafirah but also in written language.

Language styles based on sentence structure which includes: 1) climax; 2) anticlimactic; 3) parallelism; 4) antithesis; and 5) repetitions (epizeuksis, tautotes, anaphora, epistrops, simploke, mesodiplosis, epanalepsis, and anadiplosis). Then based on whether or not direct meaning, includes: 1) rhetorical language style consists of alliteration, assonance, anastrofa, apofasis (preterisiso), apostrophe, asindenton, polisindenton, chiasmus, ellipsis, euphemism, litotes, hysteron prosteron, pleonasm and tautology, perifrasis, prolepsis , erotesis, silepsis and zeugma, correction, hyperbole, paradox, and oxymoron; 2) figurative language styles, including equality or simile, metaphor, allegory, parable, fable, personification, allusion, eponym, epithet, synekdok, metonimia, antonomasia, hypalase, irony, cynicism and sarcasm, satire, innuendo, and antifrasis [7].

Unlike Perrin [8] who distinguishing language styles into three, namely: 1) comparison, which includes metaphor, similarity, and analogy; 2) relationships, which include metonymy and syntax; 3) statements, which include hyperbole, litotes, and irony.

Language is seen as one of the spaces where conflicts of various interests, strengths, powers, processes of hegemony and rival hegemony occur. However, from all the relevant research above, no one has discussed the style of language used by national politicians. This paper will discuss how the language used by national politician Fadli Zon as a manifestation of himself as a national political figure.

\section{Method}

Based on the problem proposed in this study, namely analyzing the use of language styles used by Fadli Zon politicians, the form of research used is qualitative descriptive research. Descriptive research aims to make a description (description) systematically, factually and accurately regarding the facts, traits, and relationships between the phenomena investigated. The descriptive method used in this study aims to obtain accurate data analysis to facilitate the analysis proces

The data source is a videotape of the politician Fadli Zon which was downloaded from the youtube site. The data in this study are linguistic events in the form of oral discourse. 1. The data collection technique in this study in addition to using the recording technique also uses 
the listening technique and notes. The technique of listening and recording is done by listening to the results of the record and then recording it [9].

\section{Result and discussion}

Language style is commonly used in communication. Language style can be a marker or a person's identity. Language style according to is the quality of vision, someone's view, because it reflects the way a writer chooses and places words and sentences in his writing mechanics. Language style creates certain states of feeling, such as impressions of good or bad, happy, unpleasant and so on that are received by thoughts and feelings due to the depiction of a place, objects, a certain condition or condition[10].. Based on the results of the study, the authors found that Fadli Zon used the following language stylesv.

Table 1. Data source analysis. Fadli Zon Language Style Data.

\begin{tabular}{clc}
\hline No. & Language style & Quantity Data \\
\hline 1 & Alusio & 5 \\
\hline 2 & Repetition & 25 \\
\hline 3 & Hyperbole & 15 \\
\hline 4 & Simile & 8 \\
\hline 5 & Irony & 7 \\
\hline 6 & Metaphor & 6 \\
\hline 7 & Oxymoron & 3 \\
\hline
\end{tabular}

Below this the author will explain each example of the style of language that the author found in this study. There are seven styles of language, namely alusio, repetition, hyperbole, simile, irony, metaphor and oxymoron used by national politician Fadli Zon. Explanation of the seven styles of language used as follows.

\subsection{Alusio}

"Yes, he was from a family that had blood of fighters, there was an incarnation from Diponegoro, a great sultan, then his uncle also died in the battle at Lengkong, so it was clear that his partiality to red and white was extraordinary"

In the quotation above, Fadli Zon uses the Alusio language style. Fadli Zon compared Prabowo with Diponegoro, Sultan Agung. This seems to confirm that Prabowo is no less qualified than the two heroes because he is his descendant. Keraf states that alusio is a kind of reference that attempts to suggest similarities between people, places, or events[7].

\subsection{Repetition}

Keraf argues that repetition is repetition of sounds, syllables, words or parts of sentences that are considered important to put pressure in an appropriate context[7]..

"But we want it, sir. Prabowo can be nominated, yes, as an alternative leadership that can bring change to the nation"

"Now, right, we as an agricultural country are countries that import food from rice imports, sugar imports, wheat imports, soybean imports, all kinds of imports" 
In the quotation of the sentence above, Fadli Zon uses the repetition language style. There are "yes" and "import" vocabulary that are used repeatedly to confirm the sentence to be conveyed. In the quotation of the first sentence, data F4, the word yes means to emphasize the wishes of us here representing the Gerindra party represented by Fadli Zon. In the quotation of the second sentence, the repeated use of the word import is to emphasize the statement that the Indonesian state does a lot of import activities even though its position is an agrarian country.

\subsection{Hyperbol}

Hyperbole is a style of language that contains an excessive statement, by exaggerating something based on Keraf's opinion [7].

"Yes, he was from a family that had the blood of a warrior, there was an incarnation from Diponegoro, a great sultan, then his uncle also died in the battle at Lengkong, so it was clear that his partiality to red and white was extraordinary"

"And I think we need people who have high nationalism not to seek wealth, not to seek power, but how to exercise that power for the greatest prosperity of the people".

In the quotation above, Fadli Zon uses a hyperbolic language style. Usually the language of politicians that we often see when campaigning, Fadli Zon also uses a hyperbolic language style. Fadli Zon overstated the statement about Prabowo even though it was not yet known whether Prabowo was in accordance with what was said by Fadli Zon because he had never led a country. There is a statement about the family tree of Prabowo that descended from heroes with exaggeration using the word incarnation. The word incarnation is usually found in old manuscripts or works that identify the word incarnation with the descendants of gods or gods Fadli Zon wants to emphasize that Prabowo is a descendant of a respectable person.

\subsection{Simile}

Simile language style is also found in this research, Keraf defines a simile is a comparison that is directly stated that something is the same as something else. The words that are usually used include: like, like, like, the same, and so on[7]..

"This is also part of political education so people don't buy cats in sacks"

In the quotation above, Fadli Zon uses the simile language style. Fadli Zon uses the term buying a cat in a sack. Fadli zon wants to emphasize that in choosing a leader you must see the leader first. Do not like the expression of buying a cat in a sack.

\subsection{Irony}

The Big Indonesian Dictionary defines that irony is majas which expresses meanings that are contrary to the real meaning, for example by expressing meanings that are contrary to the actual meaning and incompatibility between the atmosphere presented and the underlying reality.

"Because Indonesia is a rich country but there are still many of our people who are poor"

In the quotation of the sentence above, Fadli Zon uses the style of the language of irony. Fadli zon wants to emphasize that Indonesia is a rich country but unfortunately our people are still poor. The words rich and poor are compared, so that they look contrasting. A very different reality where the country is rich in natural resources but its people are actually destitute. This is implied in the statement of Fadli Zon above. 


\subsection{Metaphor}

Keraf defines metaphor is a style of comparison or analogy by comparing two things directly directly, but in short form[7].

"Actually the call to make improvements is because from the start the Gerindra party was established as a means of struggle"

In the quotation above, Fadli Zon uses a metaphorical style. Fadli Zon analogizes the Gerindra party with the struggle tool. He said that the Gerindra party was a tool for a struggle to make improvements.

\subsection{Oxymoron}

Keraf states that oxymoron is a style of language that contains contradictions by using opposite words in the same phrase, and because of that, they are denser and sharper than paradox[7].

"We want to promote for example a people's economy because the current economy of capitalism has proven to be a failure"

\subsection{Discussion}

In the quotation above, Fadli Zon uses the oxymoron language style. Fadli Zon contrasts the popular economy and capitalist economy. Fadli Zon's statement is a strict statement about the economic condition of Indonesia. After all of the analysis, we can conclude Fadly zon dominant using repetition and hyperbole language style

This research it is different from the result of another research. For example in Agustin's research. She found in her research about President Soeharto has dominant in repetition dan paralisme style [11]. Another research found President Jonathan has President Goodluck as a propagandist, having employed language stylistically to arouse emotions from his opponents and the electorates at large[12]. We can compare to another research who had found In terms of speakers the style of language used by sellers and buyers is idiolectct, jargon and dialect [13]. We can compare to language style who use by JK rowling in harry poter novel who use frozen style, formal style, consultative style, casual style and intimate style[14]

\section{Conclusion}

Based on the findings and discussion, it can be concluded that politician Fadli Zon uses language style in speaking. There are seven styles of the language used by Fadli Zon, namely alusio, repetition, hyperbole, simile, irony, metaphor, and oxymoron. His language stye is different than other research we had compare in another research. The most widely used language styles are repetition and hyperbole. The use of repetition and hyperbole is used as many as twenty-five and fifteen times. Fadli Zon as a national political figure, the language he uses is still awake and polite, there is no rude saying that he said.cohesion in literary discourse.

\section{Acknowledgements}

This article was realized thanks to help from various parties. The author would like to thank all parties who are willing to contribute data to this article. The author also thanked the Lecturer who has given criticism and suggestions for the perfection of this paper. 


\section{References}

[1] Thomas, Linda \& Wareing.S. Language, Society, and Power. (New York: Routledge) (1999)

[2] Dafirah, Nyoman Weda Kusuma, I Nyoman Suarka, P. Language Style Of Didek Text In The Islands Of Selayar, South Sulawesi Province. Vol 9, Pp 41-51. E-Journal Linguisitcs, (2015)

[3] ) Sartini, N. W. Bahasa Dan Pencitraan: Strategi Kebahasaan Dalam Wacana Politik. Vol 1(2), Jurnal Tutur: Cakrawala Kajian Bahasa-Bahasa Nusantara, PP 171-179. (2015)

[4] Handayani, Y, Yuni, \& Riskawati, Representasi Tindak Tutur Calon Gubernur Sulawesi Selatan: Analisis Wacana Kesopanan Berbahasa.. Jurnal Makara, Sosial Humaniora 16 (2), 116-122. (2012)

[5] Budiyanto, D. Aspek Persuasif Dalam Bahasa Iklan Partai Politik., Vol 13(1), Jurnal LITERA pp 43-52. (2014)

[6] Susilowati, E. Gaya Bahasa dalam Novel Pesantren Impian Karya Asma Nadia. Jurnal Bastra, Vo 1(2). (2016)

[7] Keraf, G. Diksi dan Gaya Bahasa. (Jakarta: Gramedia Pustaka Utama) (2002)

[8] Tarigan, H.G. Membaca sebagai Suatu Keterampilan Berbahasa. (Bandung :Angkasa) (1995)

[9] Subroto,E.D. Pengantar Metode Penelitian Linguistik Struktural. (Surakarta: UNS Press) (1992)

[10] Achmadi, M. Materi dasar pengajaran komposisi bahasa Indonesia. (Jakarta: Depdikbud Dirjen Pendidikan Tinggi PLPTK) (1988)

[11] Agustin. Diksi dan Gaya Bahasa dalam Pidato Presiden Soeharto .Skripsi (Surakarta: Universitas Muhammadiyah Surakarta.) (2008)

[12] Bolarinwa, O.R. A Stylistic Analysis of Language of Politics in the Acceptance Speech of President Goodluck Jonathan. Vol 2 (12), 37-46 International Journal For Research In Educational Studies. (2016)

[13] Zulkifli. an analysis of language style in online Facebook transactions. Vol 4 (4), Pp 81-82. International Education \& Research Journal [IERJ] (2018)

[14] Jamil, R.F \&Nasrum. Language style used in J.k. Rowling's Harry potter and the cursed child. Vol 5 (2), Pp 190-200 Jurnal Elite (2018) 